ISSN : 2641-1446 (Online) ISSN :2356-2404 (Print)

Homepage: https://journal.uir.ac.id/index.php/jshmic

Vol 9 No 1, February 2022

\title{
Analysing the Speaking and Writing Competence of an Indonesian Student in the USA: A Case Study
}

Delvia Roza

Universitas Muhammadiyah Riau

delviaroza200785@gmail.com

\begin{abstract}
Underpinning the theory of Communicative Competence (CC) proposed by Celce-Murcia, this case study focuses on evaluating the communicative competence of an Indonesian student who is studying in the USA through his writing and speaking performance. The spoken data was collected by face-to-face interview through the Skype application, while the written data was collected through email and in a form of Microsoft Word file, and analysed with the CC theory. It was found that the participant demonstrated well in both speaking and writing. However, it was also found that the participant had limitations in Linguistic competence (grammar) in both speaking and writing as well as Strategic competence (fluency) in speaking. Therefore, compensation strategies suggested by Oxford can be applied, such as code switching, native speakers or peer assistance, mime or gestures, avoiding communication, being smart in selecting the topic, adjusting or altering the message, coining words and using synonym.
\end{abstract}

\begin{abstract}
ABSTRAK
Berdasarkan teori Kompetensi Komunikasi oleh Celce-Murcia (2008), studi kasus ini fokus pada evaluasi Kompetensi Komunikasi seorang mahasiswa Indonesia yang sedang studi di Amerika Serikat melalui kinerjanya dalam berbicara dan menulis. Data lisan dikumpulkan dengan wawancara tatap muka melalui aplikasi Skype, sedangkan data tulisan dikumpulkan dalam bentuk Microsoft Word, dan dianalisa dengan menggunakan teori Kompetensi Komunikasi. Hasil analisa data menunjukkan bahwa partisipan berbicara dan menulis dengan baik. Akan tetapi, ditemukan juga bahwa partisipan memiliki keterbatasan dalam kompetensi Linguistik (Grammar) dalam berbicara dan menulis, dan kompetensi Strategis (kelancaran) dalam berbicara. Oleh karena itu, strategi kompensasi yang disarankan oleh Oxford dapat diaplikasikan, seperti alih kode,
\end{abstract}

\author{
KEYWORDS \\ celce-murcia; \\ communicative \\ competence; speaking; \\ writing
}


Delvia Roza

J-SHMIC : Journal of English for Academic

Vol 9, No 1, February 2022

bantuan dari pembicara asli atau teman sebaya, mimik atau isyarat, menghindari komunikasi, cerdas dalam memilih topik, menyesuaikan atau mengubah pesan, menyusun kata-kata dan menggunakan sinonim.

\section{INTRODUCTION}

Not long after the proclamation of freedom in Indonesia, English was chosen as the first foreign language in the country instead of Dutch, the language of People of Netherlands who ruled Indonesia for centuries (Mistar, 2005). The reason was because Dutch was the language of colonialist, and it did not have an international status as English (Lauder, 2008). Given this fact, English has been taught at schools, becoming one of compulsory subjects, and treated similarly with Indonesian language or Bahasa Indonesia in the school curriculum. However, English in Indonesia is still viewed as a difficult language to learn due to the different structure and grammar from Bahasa Indonesia. The way it is spoken and written has become the primary problem of Indonesian students in learning English. Furthermore, the diversity of dialects and cultural backgrounds of people across Indonesia also makes it difficult to learn (Gupron, 2009). Since Bahasa Indonesia is also used as the national language, there is no reason for the people to learn the language (Siregar, 2010).

Despite the issues of English as a foreign language in Indonesia, (Lauder, 2008) states that it is now considered as an access to international markets, scientific knowledge and expertise, and it is needed for the country's development, especially for researchers and academics. Nowadays, many Indonesian researchers and lecturers of universities in Indonesia, who have a work culture namely Tri Dharma Perguruan Tinggi or Three Pillars of Higher Education which requires them to do teaching and research publications (Istambul, 2019), are interested in pursuing their study and career abroad in order to open more opportunities to contribute in the global communities. Therefore, their communicative competence in English is necessary to fulfil their intentions, mainly in speaking and writing. It is because writing and speaking are the most crucial skills needed for researchers and academics, so they can do presentations in seminars and conferences internationally, give lectures in English, write English research journals and articles, and continue their study to post-graduate and post-doctoral studies abroad (Okamura, 2006).

However, according to Hertz et al. (2016), speaking anxiety was found from the presentations done in academic settings. The anxiety is caused by the fear of negative evaluation of being criticized in depending too much words appeared in the power point presentation which many researchers and academics do in seminars and conferences. In addition, Abrar \& Mukminin (2016) also state that language barrier was one of the biggest challenges for them who pursue their degrees in the English-speaking countries. It affects their performance in the classroom discussion due to their limitations in vocabulary, grammar, accent and fluency. In term of writing, Adnan (2009) in his research argue that language transfer from the first language to the foreign language in writing English language journals might cause Indonesian researchers to get rejections. The reason of the rejection was their writing in English was still influenced by their first language discourse pattern. Based on the problems mentioned, a case study was conducted to evaluate the communicative competence of a researcher who is studying in the United States. In 
this study, it is expected to perceive his strengths and limitations in terms of six communicative competences (CC) - as suggested by Celce-Murcia (2008) - in speaking and in writing.

\section{The Theory of Communicative Competence (CC)}

The theory of communicative competence (CC) was coined by Dell Hymes in the 1960s and emphasized that grammatical rules are not enough to produce the speaking and other language skills which enable communication. In 1995, Celce-Murcia et al. (1995) proposed that linguistic competence, strategic competence, sociolinguistic competence, action competence, and discourse competence were parts of CC. Nevertheless, in 2008, she revised the proposed parts of the CC into sociocultural, discourse, linguistic, formulaic, interactional and strategic competences. Sociocultural competence is related to the social and cultural context of communication; discourse competence is about how to select, sequence and arrange words, structures and utterances in order to integrate a spoken message; linguistic competence refers to four types of knowledge: phonological (sound), lexical (vocabulary), morphological (parts of speech), and syntactic (word order or sentence structure); formulaic competence defines those chunks of language that speakers frequently use in everyday interactions; interactional competence means how to perform common speech acts in the target language in conversation and interactions; and strategic competence encompasses techniques for dealing with difficulties and limitations in using English, such as gestures and memorization (Celce-Murcia, 2008). Therefore, the CC is not about grammatical language skills, but rather about how a communication plays role in interactions and builds relationships in specific communicative situations (Rickheit \& Strohner, 2008).

Several studies have discussed about the theory. Hakim \& Saputra (2018) have determined the strengths and weaknesses of a learner of English as a foreign language by using this CC theory. The other study about CC is also conducted by Poolsawad et al. (2015) about the ability of using and interpreting the English language properly based on the situation as well as expressing the attitude towards communication in cultural context. However, the theory was used to find an approach of how to improve the students' speaking performance through their speaking errors. Likewise, Usó Juan \& Martínez Flor (2008) also used the CC theory as an approach for the learners to acquire the communicative ability, but in four language skills, such as listening, reading, speaking and writing.

\section{METHOD}

\section{Setting and Participant}

The participant of this study was a 33-year-old researcher working in one of government institutions in Indonesia, and was studying in a university in the United States. He used Bahasa Indonesia both at home and work, but spoke English during his study in the U.S. He began studying English when he was in junior high school and has spent most of his time in Indonesia. The author chose this participant because: 1) his mother tongue was not English, 2) his major was not English, 3) he began studying English from the beginner level, 4) he was studying abroad, and 5) due to his job, he wrote journals and join conferences. Previously, the participant had taken TOEFL-IBT when he applied for university entrance and achieved 82. It means that he was considered to be at advanced level. The reason why he was still studying English was that as a researcher, he must read and write English journals. As Okamura (2006) states, scientific research findings must be written and published in English, even if the researchers are from non-native 
English-speaking countries. Since he lived in the U.S., he had to communicate with the local people in English.

When the participant was in junior high school, he was taught to memorize numbers of vocabulary. He thought that such learning strategy was difficult for him when encountering some low frequency words which he did not know the meanings yet. Laufer (1977) argued that according to many teachers, vocabulary is secondary importance in teaching, as there are two ways of learning it: guessing and using a dictionary. Lawson \& Hogben (1996) also suggest that the learner should conduct analysis by elaborating and constructing complex words in order to produce subsequent recall. Related to this statement, the participant agreed that the teachers should have used difficult vocabulary in sentences so he would have been able to understand and use communicative methods instead of memorizing, because using English means to communicate and comprehend communication. Based on his opinion, memorizing is not effective in teaching English. (Yang, 2011) support the argument that such memorization is timeconsuming and can be quickly forgotten, and state that if learners are taught to memorize, it helps with the dependence of the learners, but its use is not recommended.

At the time, the participant felt like communicating in English was challenging. When communicating with local people, there was a fear that - even though he understood what they had said - they did not understand what he had said or what opinion or idea he had delivered, especially in classroom discussions. However, he was trying to speak with gestures and the help of his body language. Indeed, body language and gestures are strategic competences in sustaining communication, compensating for limited knowledge and helping improvement (Savignon, 1983).

\section{Data Collection and Analysis}

To collect the data about the participant's ability in speaking and writing, he was given spoken and written tasks in an IELTS-like test format. Karim \& Haq (2014) believe that the speaking IELTS test is suitable for test takers. Based on the format of the questions in the IELTS speaking test, it can be concluded that the test ranges from easy to difficult.

In the writing task, the participant was asked to write two models of the IELTS-like writing test, Academic and General Training. Since the participant is a researcher, the academic writing was intended to investigate his ability in formulating language in scientific and academic areas, while the general training writing was intended to investigate his ability in writing in a social context.

In collecting the data for the speaking task, the researcher employed the Skype application to conduct an interview, due to the considerable distance between the researcher and the participant. According to Gubrium \& Holstein (2001), online interview has great advantages, as the cost is lower, and it is accessible in terms of location and time. However, it also has the technical challenges in the implementation which can be problematic, such as bad signal, broken sounds and noises. For the writing task, the author sent participants the test materials via email, and the data obtained was in the form of Microsoft Word. The spoken data was transferred into a transcription, and after all of the data had been collected, the competence of the learner was analysed based on the definitions of competencies proposed by Celce-Murcia (2008). All in all, the online interview and the test material delivery done via email were done successfully, and considered the most convenient and affordable instruments for the data collection. 


\section{FINDINGS AND DISCUSSION Speaking Task Evaluation}

The researcher conducted a virtual interview with the participant through Skype, which was successfully recorded. The video format was advantageous as it recorded both audio and visual interaction between the researcher and participant, so reducing constraints in transcribing (Hanna, 2012). The interview transcription is shown in Appendix II

\section{Sociocultural competence}

Based on the interview, it was found that the participant had sense of politeness in responding to the author's request (see the interview transcription in line 3), he said "yes, ma' am" in responding to a question, and he also introduced himself well formally (see line 5-7). As Cohen and Olshtain (1981) state, one aspect of sociocultural competence is to react in a culturally acceptable and appropriate way within a context. In addition, in line 9 ("are you satisfied with that?"), the participant was asking questions in a non-formal way. Celce-Murcia et al. (1995) argue that that formality is part of sociocultural components.

\section{Discourse Competence}

During the interview, the participant was successful in connecting words using conjunctions when talking and managed to be coherent in delivering his ideas. For instance, in line 20 he said "...I have no idea to answer that question because it's not my tradition to give uh... flower, bunch of flower to the other people but if you ask me to that question, I would answer to the special person that I love it I want to give that her uh... flowers..." In relation to this, we can refer to Rivera's (1984) notion that the discourse competence of a learner is their ability to unify words either in a spoken or written context. Despite successfully linking words, the participant used excessive "buts" and "ands" in many sentences he produced. In some parts, he also used incorrect pronouns to replace nouns, such as in line 25 when he explained, “... we use that jasmine flower and rose flower...". Hatch (1992, cited in Celce-Murcia et al., 1995), states that deixis is one of the important parts of discourse competence, since it links to situational contexts and makes pronouns intelligible. This means that the participant failed to demonstrate one important points of $\mathrm{CC}$, as mistakenly using pronouns can cause misunderstanding and misinterpretation.

\section{Linguistic Competence}

Some grammatical and lexical errors were produced by the participant, such as subject and verb agreements, tenses, parts of speech, clauses and common errors in constructing sentences. For example, in transcription lines 34-50, the participant was supposed to recount his experience about a meeting he remembered mostly in the past tense, but he talked mostly in the present tense, saying in line 34, for example, “...I forgot the date but it's... it was in December 2013. And... we are discussing a lot at that meeting." Another case is that some subjects did not agree with present tense verbs, such as in lines 35-36: “...the people that has authority about the..." $\mathrm{He}$ should put have in the present or had in past tense, since people is plural. According to Rivera (1984), CC must be associated with linguistic competence. Nevertheless, Hymes (1972, cited in Rickheit \& Strohner, 2008) argued that CC is not always about linguistic competence, but other varied competencies. However, in this case, he should have been aware of some grammatical rules in constructing sentences. 


\section{Formulaic Competence}

There were interesting chunks of words spoken by the participant which were related to the formulaic competence. The participant used the phrases "something like that", and "yeah, I think that's all" in lines 7, 26 and 50, which are very commonly used in daily interaction (CelceMurcia, 2008). In addition, the way he introduced himself in line 5 to 7 (...my name is... And today... err... I'm studying in University of Georgia. And I'm taking my master degree at the university. And my major is entomology, especially in... honeybee.). Further demonstrates formulaic competence. It is believed that the use of formulaic competence is to avoid negative transfer of the target language (here, English) and to control the participant's insufficient knowledge (Taguchi et al., 2013). Conversely, according to some researchers, the use of formulaic language was largely neglected until the issue was brought to wider attention in research (Celce-Murcia, 2008).

\section{Interactional Competence}

When asked by the interviewer, the participant described his feelings and opinions by using sentences like "I have no idea...", "I think...", "I prefe...", "I cannot imagine..." (see lines 15, 17, $20,21,24,42,46,48,49,50)$. This is called action competence and is part of interactional competence, where a learner exchanges information regarding his information, feelings, opinions, problems and expressions during communication (Celce-Murcia, 2008). Moreover, the dialogue (see lines 5 and 50), showed the participant had the ability to start and end his talk appropriately.

\section{Strategic Competence}

The frequent use of "I mean..." by the participant in lines 15, 27, 44 and 46 is one of examples of strategic competence, where he attempts to repair his speaking ability. The sound of "uhh..." was also included in many instances of the participant's responses. It can be considered as a strategic competence device where he showed hesitation and produced the sound in order to take time to recall vocabulary or construct sentences (Celce-Murcia et al., 1995; Celce-Murcia, 2008). Even so, Chomsky (2014) points out that these sounds are not considered proper and do not belong to linguistic theory, so it can be concluded that they should not have been used frequently, since they are noticed by the interlocutor.

\section{Writing Task Evaluation}

The written data given was two models of IELTS-like writing test, Academic and General Training tests. The tests were sent by email and, they were answered and typed by the participant in the format of Microsoft Word. The written data was taken by this method due to the distance between the author and the participant.

\section{Sociocultural competence}

In the written task, the participant mentioned called Jakarta in academic writing (AW) part 2, which indicates his background. He explained the situation relating to the social and cultural experience that he had there. The other place mentioned was Raja Ampat island, mentioned in general training writing (GTW) part 2. Celce-Murcia et al. (1995) state that historical background and knowledge of life and traditions could be one factor in a successful and comprehensive communication. Similarly, the participant successfully delivered his idea by depicting the society and culture in Indonesia in the written tasks. 


\section{Discourse Competence}

The written data obtained was considered coherent as both texts described real-world examples, as shown in the AW part 2. Witte and Faigley (1981) view that coherence must be understood in a real-world setting. In addition, some transition words - which connect one sentence to other sentences and make them into a cohesive text - were recognized, relevant here as Witte and Faigley (1981) also added that cohesion means how a text holds together.

\section{Formulaic Competence}

There were "chunks" of words encountered, such as "I hope this email finds you well", "for your information..." (GTW part 1), "for example..." (GTW part 2), "as we know...", "as a result...", and "for instance..." (AW part 2). These words enabled the participant to avoid linguistic components (Celce-Murcia, 2008), but the participant mostly used word chunks for academic situations.

\section{Linguistic Competence}

There were several errors found in the written task assigned to the participant. Firstly, subject and verb agreement errors were located in AW parts one and two, as well as GTW part two, such as: "...raw material $(s)^{1}$ used in making cement are..." (AW part 1); "there are many reason(s)..." (AW part 2 \& GTW part 2); "the number of traffic is (omit) significantly decrease $(s) . . . "$ (AW part 2). Moreover, there were also several errors in expressions of quantity with singular or plural nouns "many reason(s)" (AW, part 2 \& GTW, part 2), "other culture(s)" (GTW, part 2); pronoun reference: "because those materials have different structure, it is (they are) ..." (AW part 1); and the use of present and past participle: "...the next stage is heated and rotated (heating and rotating)". Since the grammatical errors were not overly prevalent, participant seemed ignoring them appropriately with what Ellis (2006) stated that the language learners are considered to ignore their errors. In their finding, Maros et al. (2007) conclude that the cause of errors may stem from interferences of the mother tongue. Since in Bahasa Indonesia there are no specific grammatical rules in agreements, pronoun references, etc., the participant might unconsciously be using the same patterns in his English sentences.

\section{Interactional Competence}

AW and GTW part 2 required the participant to give opinions, and he performed well in the argumentative text (see appendices), which is interactional. According to Celce-Murcia, et al., (1995), interactional competence involves in expressing opinions, problems, and giving 
information. However, the perspectives of interactional could be different. What the participant wrote could possibly be inappropriate in other interactional communities, such as what stated in the email "For your information, my house now has 4 bedrooms, 4 walk in bathrooms, and your own balcony!!” (See appendices, written task, GTW 1) which can be used with friends, family in an informal situation instead of with superiors, teachers in a formal situation.

\section{Strategic Competence}

In AW part 2, the participant used the words "as we know..." to strategize how he delivers his idea to readers as the effort of interacting (Celce-Murcia, 2008). In AW part 1, it was found that the participant also paraphrased the sentence in the question into a simpler one. Nonetheless, changing the original sentence into another form may lead to misinterpretation (Mariani, 1994), and this could be applicable to what the participant wrote.

\section{CONCLUSIONS}

This study focuses on the analysis of the communicative competence of an Indonesian student who is studying in one of universities in the USA. The main focus was in the speaking and writing competence. The competences were evaluated by the theory of Communicative Competence suggested by Celce-Murcia (2008) which consists of sociocultural competence, Discourse competence, Formulaic competence, Linguistic competence, Interactional competence, and Strategic competence. The theory of CC is assumed to be engaged with knowledge, skills and human action (Rivera, 1984). Through data analysis, it can be concluded that the participant demonstrated well in the CCs both in speaking and writing, despite some limitations found in his work, especially regarding grammar, which is related to linguistic competence.

Another issue in participant's speaking was fluency. Numerous "uhh..." sounds were noted when the participant was talking. Though this is part of strategic competence, it affected the participant's spoken fluency. It is said that the acquisition of speaking fluency is correlated with the opportunities to speak the language (Dustmann, 1994). Celce-Murcia (2008) also argues that insufficient knowledge of grammar and pronunciation will result in limited oral competence: fluent, but inaccurate. Hence, grammar is considered important in speaking. Therefore, the strategy of the participant in improving his fluency is to use his opportunity staying in the U.S. to communicate with the native speakers there as much as possible.

It is also suggested that the participant can apply the Compensation Strategy by Oxford (1990) in dealing with both speaking and writing. The strategies are such as switching language into mother tongue (code switching), getting help from native speakers or peer assistance, using mime or gestures, partially or totally avoiding communication, being smart in selecting the topic, adjusting or altering the message into something which is slightly different, coining words (making up words) and using synonym. These strategies are intended to make the language learners stay in a conversation and keep writing (Oxford, 1990). 


\section{REFERENCES}

Abrar, M., \& Mukminin, A. (2016). International Graduate Classroom Discussion Engagement, Challenges, and Solving-Strategies. Asia-Pacific Collaborative Education Journal, 12(1), 519.

Adnan, Z. (2009). Some potential problems for research articles written by Indonesian academics when submitted to international English language journals. The Asian EFL Journal Quarterly, 11(1), 107-125.

Celce-Murcia, M., Dornyei, Z., \& Thurrell, S. (1995). Communicative Competence: A Pedagogically Motivated Model with Content Specifications. Issues in Applied Linguistics, $6(2)$.

Celce-Murcia, M. (2008). Rethinking the role of communicative competence in language teaching. In Intercultural language use and language learning (pp. 41-57). Springer, Dordrecht.

Chomsky, N. (2014). Aspects of the Theory of Syntax (Vol. 11). MIT press.

Cohen, A. D., \& Olshtain, E. (1981). Developing a measure of sociocultural competence: The case of apology. Language learning, 31(1), 113-134.

Dustmann, C. (1994). Speaking fluency, writing fluency and earnings of migrants. Journal of Population Economics, 7(2), 133-156.

Ellis, R. (2006). Current issues in the teaching of grammar: An SLA perspective. TESOL quarterly, 40(1), 83-107.

Gubrium, J. F., \& Holstein, J. A. (2001). Handbook of Interview Research 1 From the Individual Interview to the Interview Society. Sage Handbook of Interview Research.

Gupron, A. K. (2009). Hubungan Antara Kemampuan Berbicara Bahasa Inggris dengan Hasil Toefl pada Taruna Sekolah Tinggi Ilmu Pelayaran (STIP) Jakarta. Widyariset, 12(3), 61-66.

Hakim, M. A. R., \& Andri, S. (2018). How A Learner Learns and Acquires English as A Foreign Language: A Case Study. The Journal of Asia TEFL, 15(3), 838-845.

Hanna, P. (2012). Using internet technologies (such as Skype) as a research medium: a research note. Qualitative Research, 12(2), 239-242.

Hatch, E. (1992). Discourse and language education. Cambridge University Press.

Hertz, B., Kerkhof, P., \& van Woerkum, C. (2016). Powerpoint slides as speaking notes: The influence of speaking anxiety on the use of text on slides. Business and Professional Communication Quarterly, 79(3), 348-359.

Hymes, Dell. (1972). On communicative competence. Sociolinguistics 269293: 269-293.

Istambul, M. R. (2019). The impact of i-performance in changing the work culture of lecturers to increase the productivity of three pillars (tri dharma) of higher education in Indonesia. Universal Journal of Educational Research, 7(4), 15-21.

Karim, S., \& Haq, N. (2014). An Assessment of IELTS Speaking Test. International Journal of Evaluation and Research in Education, 3(3), 152-157.

Lauder, A. (2008). the Status and Function of English in Indonesia: A Review of Key Factors. Makara Human Behavior Studies in Asia, 12(1), 9.

Laufer, B. (1981). A problem in vocabulary learning-synophones. ELT Journal, 33(3), 294-300.

Lawson, M. J., \& Hogben, D. (1996). The vocabulary-learning strategies of foreign-language students. Language learning, 46(1), 101-135.

Mariani, L. (1994). Developing strategic competence: Towards autonomy in oral interaction. Perspectives, 20(1), 41-57. 
Maros, M., Tan, K. H., \& Salehuddin, K. (2007). Interference in learning English: Grammatical errors in English essay writing among rural Malay secondary school students in Malaysia. $e$ BANGI: Jurnal Sains Sosial dan Kemanusiaan, 2(2), 15.

Mistar, J. (2005). Teaching English as a foreign language (TEFL) in Indonesia. Teaching English to the world: History, curriculum, and practice, 75-85.

Okamura, A. (2006). Two types of strategies used by Japanese scientists, when writing research articles in English. System, 34(1), 68-79.

Oxford, R. L. (1990). Language learning strategies: What Every Teacher Should Know. Boston: Heinle and Heinle Publishers.

Poolsawad, K., Kanjanawasee, S., \& Wudthayagorn, J. (2015). Development of an English communicative competence diagnostic approach. Procedia-Social and Behavioral Sciences, 191, 759-763.

Rickheit, G., \& Strohner, H. (Eds.). (2008). Handbook of communication competence (Vol. 1). Walter de Gruyter.

Rivera, C. (Ed.). (1984). Communicative competence approaches to language proficiency assessment: Research and application (Vol. 9). Multilingual matters.

Savignon, S. J. (2018). Communicative competence. The TESOL encyclopedia of English language teaching, 1-7.

Siregar, F. L. (2010). The language attitudes of students of English literature and D3 English at Maranatha Christian University toward American English, British English and Englishes in Southeast Asia, and their various contexts of use in Indonesia. Philippine ESL Journal, 4(4), 66-92.

Taguchi, N., Li, S., \& Xiao, F. (2013). Production of formulaic expressions in L2 Chinese: A developmental investigation in a study abroad context. Chinese as a Second Language Research, 2(1), 23-58.

Usó-Juan, E., \& Martínez-Flor, A. (2008). Approaches to language learning and teaching: Towards acquiring communicative competence through the four skills. In Current trends in the development and teaching of the four language skills (pp. 3-28). De Gruyter Mouton.

Witte, S. P., \& Faigley, L. (1981). Coherence, cohesion, and writing quality. College composition and communication, 32(2), 189-204.

Yang, W. (2011). Rote Memorization of Vocabulary and Vocabulary Development. English Language Teaching, 4(4), 61-64.

\section{APPENDICES}

\section{Appendix I}

\section{Spoken Data Transcription}

I: Interviewer

P: Participant

I: good evening, sir. My name is Delvia. I would like to interview you for my language learnin assignment. Are you ready to take the interview?

P: yes, ma'am.

I : okay. Uh.. first of all, can you tell me about yourself, please? 
P: oh, yeah. Uh.. uh.. my name is Avry Pribadi. And today.. err.. I'm studying in University of Georgia.

And I'm taking my master degree at the university. And my major is entomology, especially in honeybee. Yep, I think that's all.

I: okay. Uhh.. let me [are you] ask ss.. about..

P: are you satisfied with that?

I: (laugh) that okay. That's enough, okay. That's enough information for me. Okay, let's go to.. ee. questions about flowers. Ee.. do you like to have flowers in your home?

P: oh, yeah, absolutely. I love flower, though.

I: okay, where would you go if you want to buy flowers?

P: uh.. actually, there are many places that I love to buy the flower, but the most I love is in the (pause) uh.. in the places that available (pause) a p.. I mean along the street. I think it's more fresh I.. in my opinion. So I can choose which one is much better, and which one is bad, instead of I'm going to the.. supermarket for that. I.. yeah, it's good but.. for me I prefer to choose the.. the market that which is available in along of the street.

I: okay. On what occasions would you give someone flowers?

P: uhh.. actually I have no idea to answer that question because it's not my tradition to give uh.. flower, bunch of flower to the other people but if you ask me to that question, I would answer to the special person that I love it I want to give that her uh.. flowers.

I: okay. Uh.. Are flowers important in your culture?

P: uh, yeah. Uh.. I can say that it's very-very important especially the flowers.. It can be used for.. uh..like a ceremony or traditional ceremony in my place. And we use that jasmine flower and rose flower to make it's more beautiful and also and we come to the funeral, something like that. We do also use the flowers to give some (pause) uh.. I mean decoration to funeral like that.

I: okay. Okay, let's go now to part two. It's about describing a meeting you remember going to at work, college or school. And.. you have one minute to write about the.. material that you want to deliver in the topic, and I will give you about two minutes to talk about the topic. Okay, one minute starts now.

(one minute later)

I: okay, time is up. You may start your monologue now for one until two minutes.

P: uh.. yup. A meeting that I uh remember was when.. in Bogor.. actually. In.. I forgot the date but it's..it was in December 2013. And.. we are discussing a lot at that meeting, because uh.. it is not only me that attend to that uh.. the meeting, but also the people from the other forest legacy or.. the people that has authority about the.. forest comes to the meeting, eh.. to discuss about how we can increase the.. uh.. nontimber forest product. So.. in that (pause) uh.. meeting I was presenting about the other alternative of using of the non-forest timber product, such as the.. by using the honey bee, it can be.. it can increase the.. it can increase (pause) increase (laugh) increase the income of the people who living around the forest. Yeah, it's.. it's really hard for the people especially for the people who has the actuality about the forest, but to understand what I'm talking about but.. by giving some example and the success story about what happen to our area, I think they can un.., they can understand what I'm talking about, and they are very intensive to.. a.. about.. what I.. I'm uh discussing. And.. and it also some people in this area, uh I mean the people who has authority to a.. the forest, they are very.. they want me to come to that area and (pause) give some workshop obtaining for the people who live in that forest to increase uh.. their income. And.. (pause) why it is very uh become.. I mean.. I (cough) I remember this meeting because the enthuastic of the people who comes to this meeting is very-very unbelievable. I cannot imagine that these people very enthuastic to ask and interact with me about the problem that they have, and about the solution I offer to them, and, and some are very impressed me. Yeah, I think that's all.

\section{Appendix III}

\section{Written Data Transcription}


J-SHMIC : Journal of English for Academic

Vol 9, No 1, February 2022

1. Academic Writing Task 1

\section{WRITING TASK 1}

You should spend about 20 minutes on this task.

The diagrams below show the stages and equipment used in the cement-making process, and how cement is used to produce concrete for building purposes.

Summarise the information by selecting and reporting the main features, and make comparisons where relevant.

Write at least 150 words.
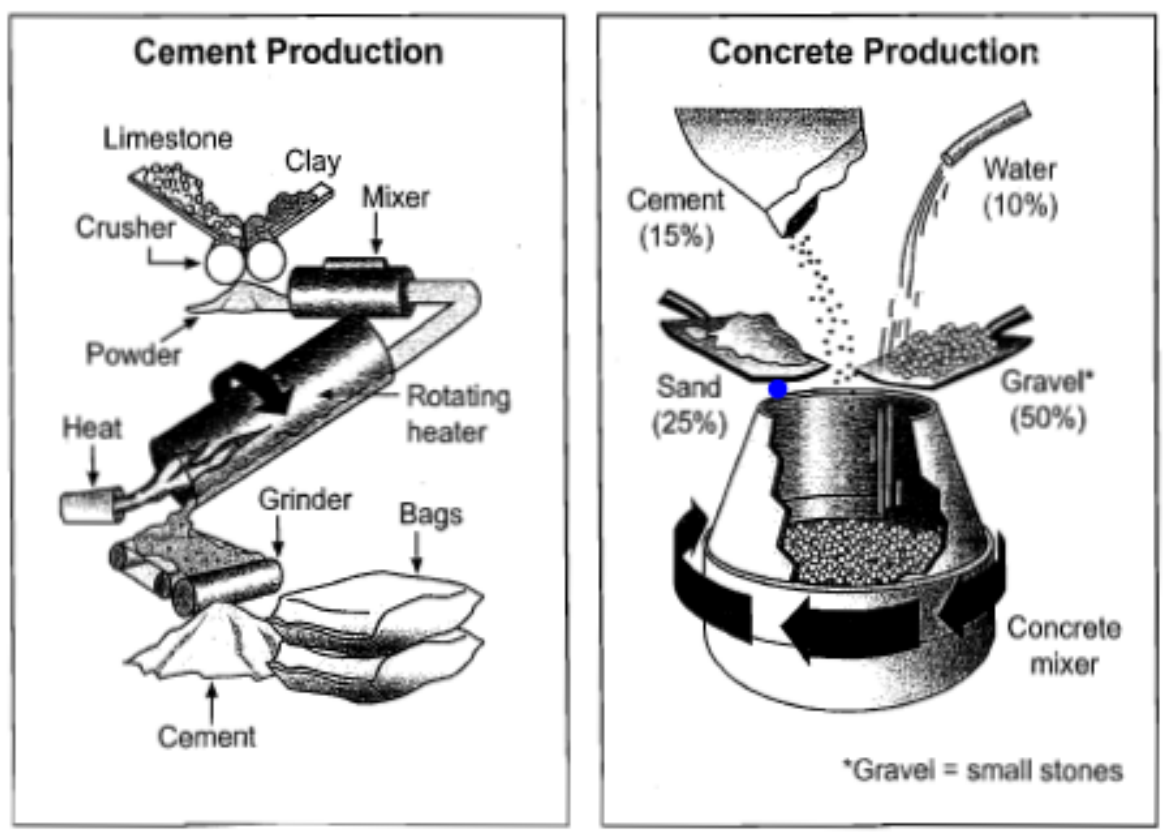

Answer:

Those pictures show two related process of using cement. The first picture explains cement production process. Basically, raw material used in making cement are limestone and clay. Because those materials have different structure, it is difficult to combine its directly. Thus, to make it easier to mix, those two compounds must be crushed. After limestone and clay are blended, the next stage is heated and rotated. The aim of this process is to get better composition and mixed properly. Last stage, this compound should be passed to grinder to make sure that it is smoother. The result of this process is called cement and it is ready to put into bags. Meanwhile, in the second picture, it describes how cement produced in first picture used in concrete production. In order to have good concrete, the picture suggests that we have to mix $15 \%$ of cement, $10 \%$ water, $25 \%$ sand, and $50 \%$ gravel. Those all compounds are mixer together by using concrete mixer. 


\section{Academic Writing Task 2}

\section{WRITING TASK 2}

You should spend about 40 minutes on this task.

Write about the following topic:

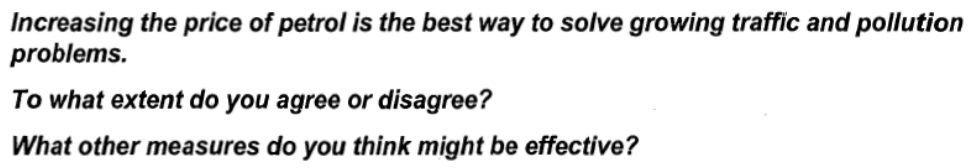

Give reasons for your answer and include any relevant examples from your own knowledge or experience.

Write at least 250 words.

\section{Answer:}

Between those options, I do agree to support in increasing the petrol price to solve problems in traffics and pollution. There are many reason why I chose this opinion. First, by increasing petrol price, it means that most people that use car and motorcycle will think twice in consuming their gas. They will reconsider and reduce utility of their vehicles. Instead of using their own vehicles, they might consider to ride together by car polling. As a result, the number of vehicles in road will decline significantly and so that, it also reduces traffic. For instance, the phenomenon of online Taxi happened in many big cities such as Jakarta. The appearance of online Taxi used as carpooling, it significantly declines traffic jam. The second reason is reducing pollution. Logically, if the number of traffic is significantly decrease, it will reduce pollution. As we know, vehicles produce a lot of pollution gas such as Nitrogen Dioxide. Many studies said that this pollution gas is main problem for causing acid rain in many countries. By reducing pollution gas accumulation in air, it will increase air quality. Furthermore, there are many methods can be used to slow traffic growth and reduce pollution such as providing mass public transportation. By providing convenient mass public transportation, many people will move from personal vehicles to public transportation. This have already happened in Jakarta where people living in remote area change and leave their vehicles at home and use commuter trains to get their offices in center Jakarta instead. In conclusion, increasing petrol price is good policy in one side, yet, it must be followed by providing comfortable and cheap mass public transportation.

\section{General Training Task 1}

\section{Writing Task 1}

You should spend 20 minutes on this task.

You have recently moved to a different house. Write a letter to an English-speaking friend. In your letter:

- Explain why you have moved 


\section{Answer:}

\section{Dear Didi Kempot,}

I hope this email finds you well.

Hi buddy, I write this mail from my new house. Yes, I move to this new brand house just couple days ago. Hence, since today you can use this address to correspondence with me. The reason why I moved to this house is duet to house rent. My new house right now is pretty cheap instead of my previous house. The other things, this house also has better environment. I mean, they have beautiful park outside and dog friendly. The last reason why I come up with this house is that it is quite close to bus stop which passed every 10 minutes. For your information, my house now has 4 bedrooms, 4 walk in bathrooms, and your own balcony!! It means that I have my own bathroom and I am so satisfied with it. It also has new kitchen that is just renovated recently and it looks fantastic. Moreover, my house also has large living room which has cable television on it. The most interested thing that I like from this house is the backyard. The backyard is outstanding large and fully of beautiful flower. I encourage you to come to my new house and I promise that you will like it very much. Just let me know when you will come to my new house and I will make big surprise for you. Cannot wait any longer to see you in my house dude.

Kindly regards,

\section{Raden Mas Sukoco}

\section{General Training Task 2}

\section{WRITING TASK 2 \\ You should spend about 40 minutes on this task. \\ Write about the following topic:}

Today more people are travelling than ever before.

Why is this the case?

What are the benefits of travelling for the traveller?

Give reasons for your answer and include any relevant examples from your own knowledge or experience.

Write at least 250 words

Answer:

It is true that today people are travelling than many previous years. There are many reason why this phenomenon happens. First is due to the existence of technology, particularly social media. Social media is the fastest media than television or even radio. By having information from social media, many people can inform about something unique places where they live and if this message is seen by other people who live in other hemispheres and they think or even curious about those places, it will encourage them to travel to come to that place. For example, by using Facebook and YouTube, people in northern hemisphere such as Europe and United States know that there is a beautiful place in tropical region quickly and most of the will find it out to come to 
the place just to kill their curiosity. The second reason is airline ticket. Nowadays, airline tickets are relatively very cheap and travelers also have many airline options to fly. Consequently, it will make more people interested to travel to other places than in the past. In Indonesia, in the last 15 years, the airline growth is very high. Second reason is accessibility. Having bad accessibility such as worse road condition like what happened in the past, it will make people think twice before they travel to other places. For instance, in the past many people do not have any idea how to travel to beautiful places such as Raja Ampat island. As a result, there are so many people that come to that place. However, when Indonesia government start to build good facilities such as harbor and airport, there are so many visitors come to see and enjoy the landscape of Raja Ampat island. Furthermore, there are many advantages for the travelers to travel. First, it will open their mind that world is not only limited to their country. By visiting other country, they can know and learn about other culture. For instance, an American that I meet up just recently do not know that Indonesia is more diverse in culture, religion, language, and cuisine than United States. Second, by travelling around the world, travelers can become free advertiser. I mean that they can tell a story to other people they meet about the previous country that they visit. It is sometimes working and there are many people who visit to that country as tourists. It definitely gives much benefit to country that they are visited. In conclusion, by giving better accessibility and advertising by social media, it will encourage many people to travel to other countries which can also give many benefit not only to that country itself but also for the travellers. 